\title{
Analysis of a Tower Crane Accident
}

\author{
M. H. Arslan* and M. Y. Kaltakci
}

Selcuk University, Engineering and Architecture Faculty, Department of Civil Engineering, Konya, Turkey

\begin{abstract}
Today, steel tower cranes are widely used in the construction sites. In this study, the accident occurred in Turkey in 2006 with the overturning of a tower crane in a construction site and the damage occurred on the nearby buildings due to this accident were taken into consideration. At first, the technical characteristics of the EC-H type tower crane used in that construction and then the reasons of the accident were presented in detail. The damage on the load carrying systems of the nearby buildings due to the accident and the precautions taken at the buildings after the accident for the improvement of the load-carrying systems were discussed. The numerical analysis and the general through investigation of the damage and the responding precautions performed for the reinforced concrete constructions were particularly carried out.
\end{abstract}

Keywords: Tower Crane, damage, accident, numerical analysis, reinforced concrete

\section{NOTATION}

\begin{tabular}{|c|c|}
\hline$\theta$ & $:$ Slope of platform and tower crane \\
\hline $\mathrm{H}_{\text {crane }}$ & $:$ Crane height \\
\hline$\delta$ & $:$ Top displacement of crane \\
\hline $\mathrm{V}_{\mathrm{pr}}$ & $:$ Punching strength \\
\hline $\mathrm{V}_{\mathrm{pd}}$ & $:$ Punching shear \\
\hline$\gamma$ & $:$ Moment transfer coefficient \\
\hline $\mathrm{u}_{\mathrm{p}}$ & $:$ Critical perimeter \\
\hline $\mathrm{f}_{\mathrm{ctd}}$ & $:$ design tensile strength of concrete \\
\hline $\mathrm{d}$ & $:$ slab clear height \\
\hline
\end{tabular}

\section{INTRODUCTION}

With the increasing demand of Turkey's construction sector in recent years, the usage of machines in the sector became more widespread. The tower crane is one of the most important machinery system frequently used in constructing the multi-storey buildings with wider construction areas. Tower crane is formed with three components namely settling apparatus, steel tower and steel lever, and it can be directed by an operator existing inside a cabin on the tower. The cost of the construction reduces with the advantages supplied by the crane during the mounting and the usage stages.

The mounting and the operating rules of the tower cranes were expressed in detail in the technical documents given by the manufacturer firms [1]. Additionally, the legal specifications related to the tower cranes are found in Turkey and in the other countries of the world. In Turkey, the standards of TS-ISO 8566-3 [2] and TS-ISO 4306-3 [3] are used for the operation of the tower cranes.

In this study, an accident of steel tower crane which was used in a construction site will be investigated. First of all,

\footnotetext{
*Address correspondence to this author at the Selcuk University, Engineering and Architecture Faculty, Department of Civil Engineering, Konya, Turkey; E-mail: mharslan@selcuk.edu.tr
}

the technical characteristics of the tower crane used in that construction and then the reasons of the accident were presented in detail. The damage on the load carrying systems of the nearby buildings due to the accident and the precautions taken at the buildings after the accident for the improvement of the load-carrying systems will be discussed. The numerical analysis and the general through investigation of the damage and the responding precautions performed for the reinforced concrete constructions will be particularly carried out.

\section{CASE STUDY}

\section{Background}

The 19-storeyed construction including luxury houses and offices began to be constructed in 2006 May on a $16120 \mathrm{~m}^{2}$ area and was formed from two apartment buildings and one office building. The general view of the construction is given in Fig. (1). Since the construction was multi-storied and was having a wider construction area, there were used two cranes of EC-H type.

One of these tower cranes was overturned in 2006 (seen at the left side of Fig. 1), and resulted in serious damages beside the death of the operator. The tower crane was $30 \mathrm{~m}$ high when

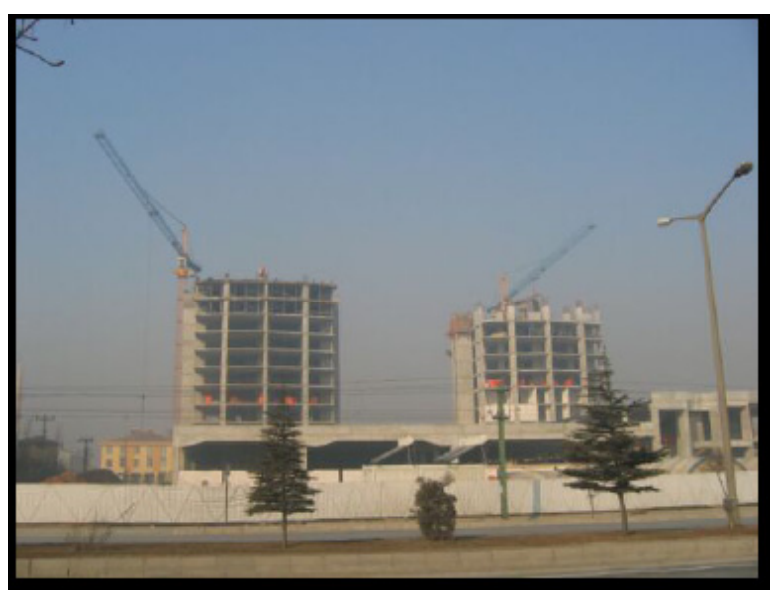

Fig. (1). General view of the construction. 
it was overturned. The building near the crane and a nearby bread factory (Fig. 2-3) faced to significant structural damages with the collapse.

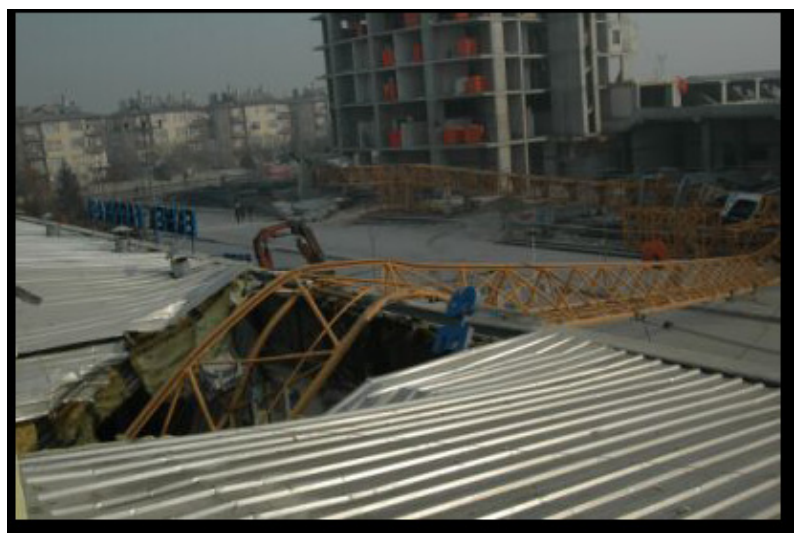

Fig. (2). Roof of bread factory.

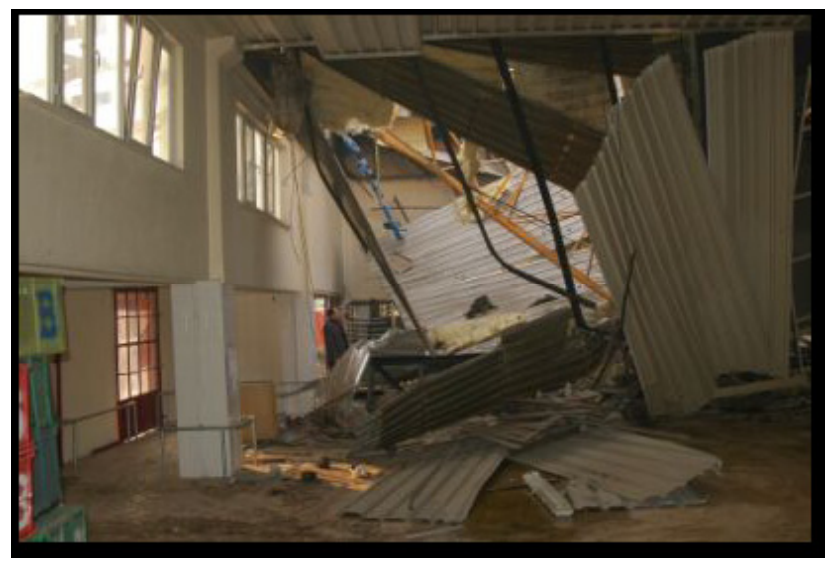

Fig. (3). Inner view of factory

Especially a reinforced concrete column and a part of the slab have met important damage. The operator of the crane got caught inside the cabin and died at the hospital. The operator's personal car became unavailable after the supports of the crane have been overturned as seen in Fig. (4). There was a big LGP tank and pipe line near the accident region (Fig. 5).

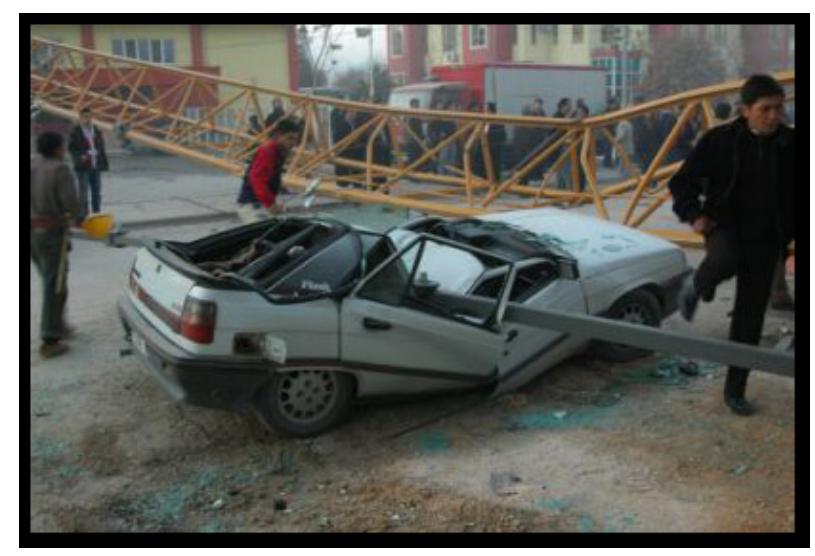

Fig. (4). Effect of the overturned crane.

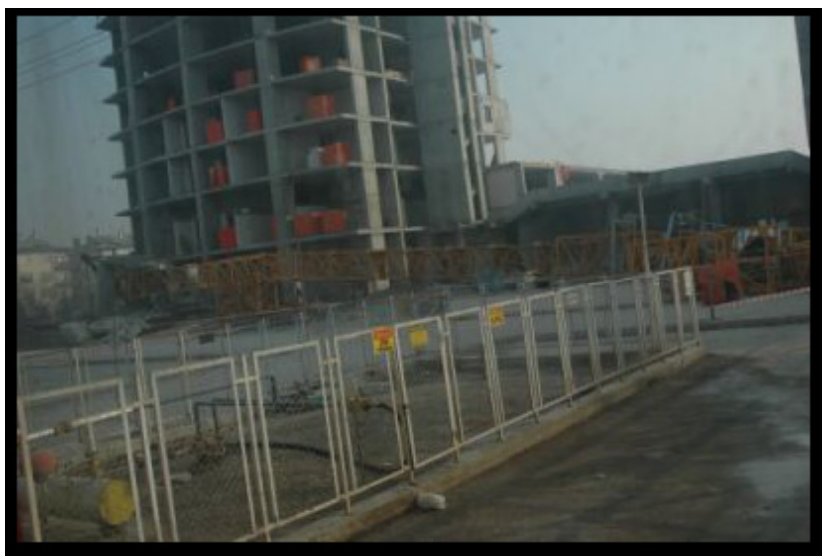

Fig. (5). Effect of the overturned crane (LPG pipe line).

\section{Technical Properties of Tower Crane}

The highly adaptable fast-erecting cranes and the efficient top-slewing cranes have proved their worth both in the construction of residential buildings and on large-scale industrial projects all over the world [1]. Tower crane are produced with steel profiles which have various types and sizes. There are limited firm which produces steel tower crane in the world. The subjected crane coded 154 EC-H6 was produced by Liebherr firm. Both loading capacity and geometrical properties are given in the firm catalog by systematically. The EC-H cranes are built in the construction size from 112 $\mathrm{m}$ to $630 \mathrm{~m}$. These cranes are powerful enough for medium to large construction projects. In the catalog [1], maximum radius is indicated as $60 \mathrm{~m}$. In this radius, the maximum vertical load is $1650 \mathrm{~kg}$. The load can increase to $4000 \mathrm{~kg}$ in the case of $40 \mathrm{~m}$ radius length. According to the Liebherr catalog, the interaction between radius and load is given in Table 1.

\section{Table 1. Hoisting Height and Mass Interaction}

\begin{tabular}{|c|c|}
\hline The crane type & EC-H Series \\
\hline \hline Mass (kg) & $1650-4000$ \\
\hline $\mathbf{k g}$ & $4000-6000$ \\
\hline $\mathrm{m}$ & 6000 \\
\hline Lateral Length & $40-60.0$ \\
\hline $\mathrm{m}$ & $\sim 20-40$ \\
\hline Vertical Height & $<\sim 20$ \\
\hline $\mathrm{m}$ & \\
\hline
\end{tabular}

\section{Causes of the Failure}

The tower crane was erected in $1^{\text {st }}$ September 2006 and then was overturned in $13^{\text {th }}$ December 2006 with the various causes. At this time the building was ground floor $+8^{\text {th }}$ typical floor level and the approximate height of the tower crane was $30 \mathrm{~m}$. The main reasons of the overturning are given as follows; 
- Not having a regular platform on which the crane foundation was settled during the assembly of the crane.

The platform on which the crane legs were settled must be smooth. According to the expert report [5], the concrete platform length was $3000 \mathrm{~mm}$ and the code differences between the both end of the platform is $20 \mathrm{~mm}$. In this situation, as given in Eq.1,

$\theta=\frac{20}{3000}=0.0066 \rightarrow \alpha=0.3819^{0}$

the slope of the platform can be calculated. This slope causes the important inclination on the tower crane. The total inclination of the tower crane is,

$\delta=\theta \times \mathrm{H}_{\text {crane }}=198 \mathrm{~mm}$

In order to adjust this top displacement, the crane was pulled on the middle level with the using a mobile crane. In the (Fig. 6), the mobile crane is seen. Since the lateral load carrying capacity of the mobile crane was not enough for adjusting the tower crane, a part of the balancing concrete block masses on the tower crane foundation were wanted to remove. But with the removing these mass blocks, the tower crane was faced incalculable turning moment by the removing these overturning safety masses.

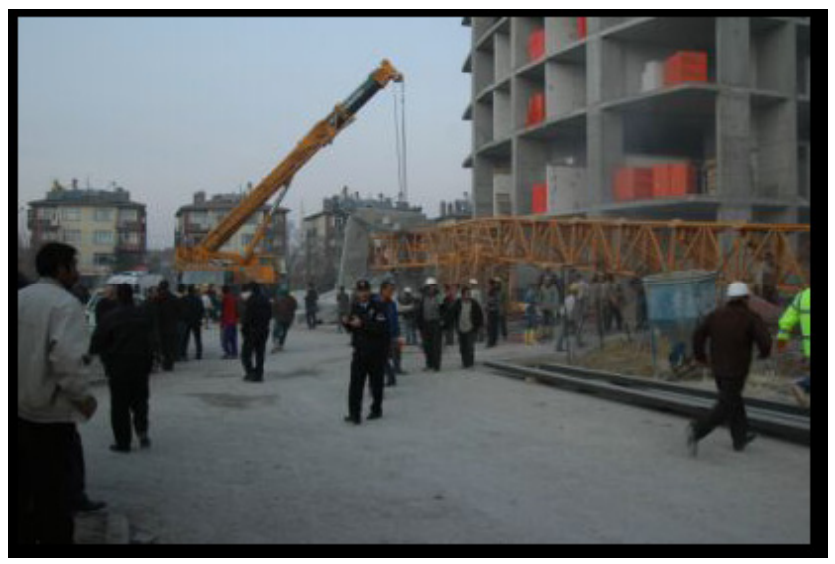

Fig. (6). Mobile crane.

- Not using anchorage members fixed the crane footings.

In the present application, beside the connection of the crane to the concrete platform has not been made, the required anchorage members have not been used in the profiles fixing the crane footings to the ground. Under this circumference, the tension force that should be carried by 8 anchorage bolts of $\phi 32$ could not be responded by any apparatus. The number of anchorages was determined according to the moment. The unbalanced moment arisen with the overturning effect of the crane's load resulted in the rotation of the crane around its footings (Fig. 7a and 7b).

- Not using the connection member between the crane and building.

Although the crane has reached the height of $30 \mathrm{~m}$, the supports that would prevent the overturning of the crane have not been made, and no other connection member has been used. In Fig. (8), the tower crane having no connection member is seen and after the failure the crane is given in Fig. (9).

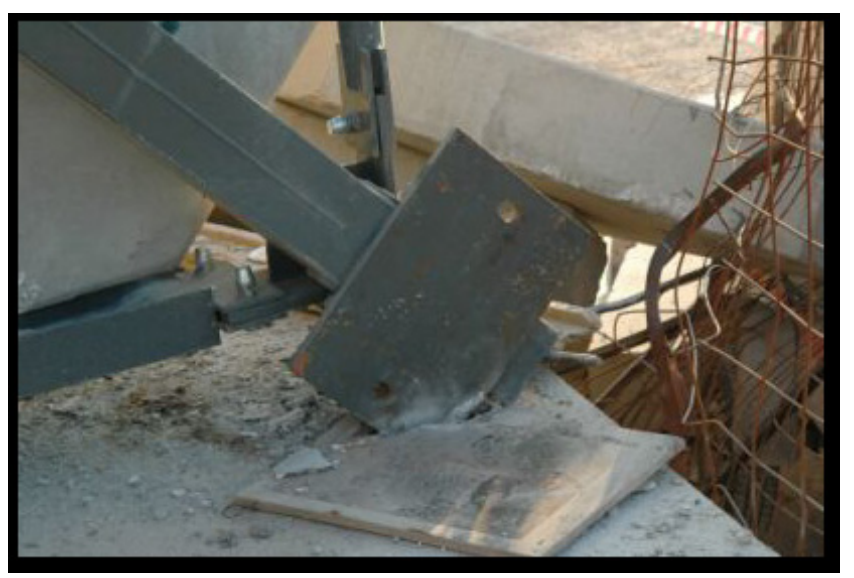

Fig. (7a). Unused anchorage members.

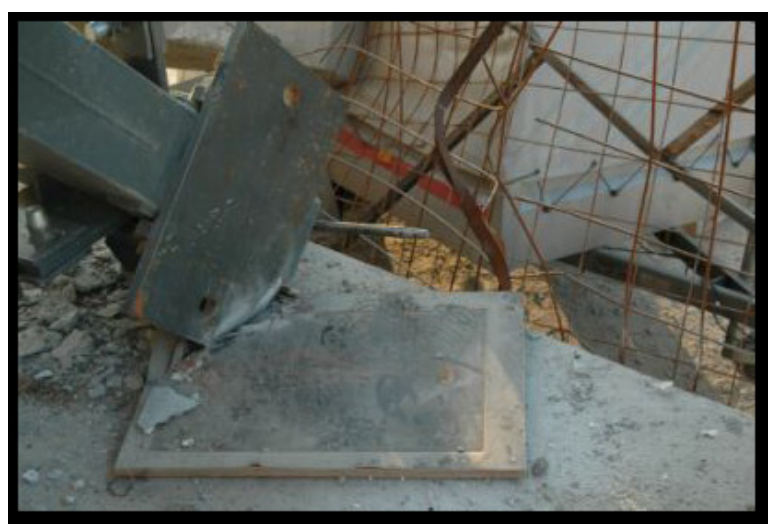

Fig. (7b). Rotation of the crane around its footings.

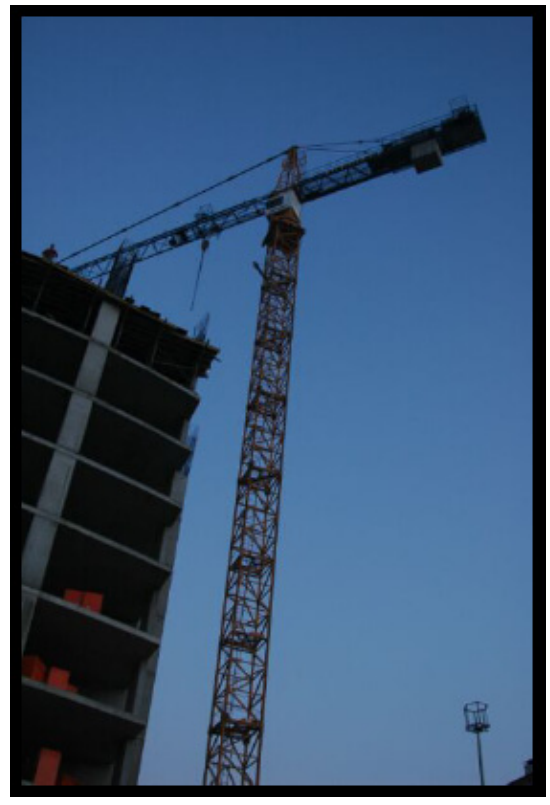

Fig. (8). Having no connection with the building (Before the failure). 


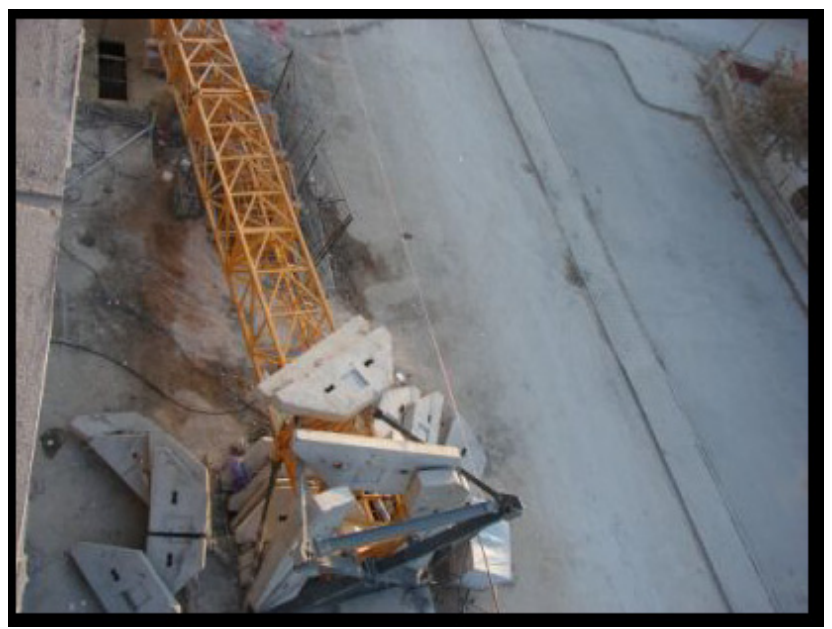

Fig. (9). After the failure.

- The extreme load at the end of the crane arm.

The most important negligence in the accident was the extreme load $(2500 \mathrm{~kg})$ at the end of the crane which was greater than the required in the code. Although the operator had license and experience for using the crane, he could not prevent the occurrence of this tragic event and lost his life. (Fig. 10) gives the technical capacity of the crane on radius and load carrying.

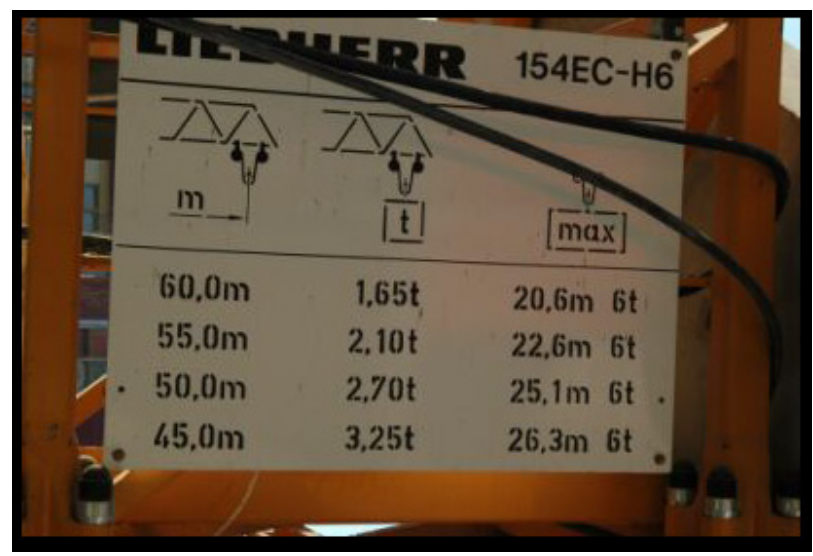

Fig. (10). Warning board on the site.

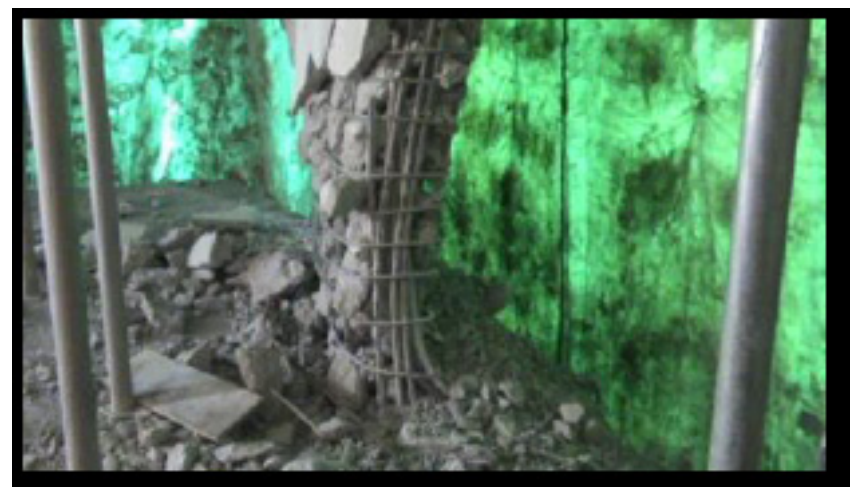

Fig. (11). The bottom of the column (narrow side).

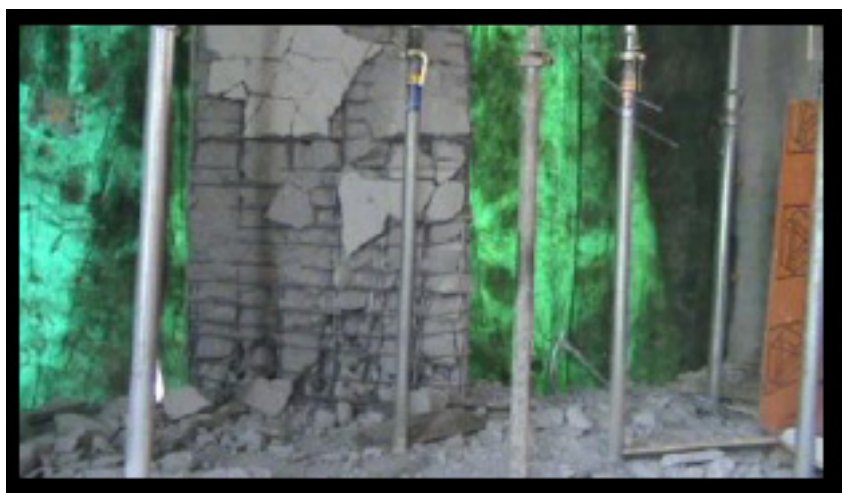

Fig. (12). The bottom of the column (wide side).

\section{EFFECTS OF THE ACCIDENT}

The building structural system consists of shear walls and columns which supports flat slabs. The flat slab is selected because of being luxury residence and commercial units in the building. The most important disadvantage of this kind of flat is having big lateral displacement capacity and punching effect. The punching failure which takes place by punching of the column through the slab forming an inverted pyramid or cone is very sudden and extremely brittle. Punching shear failure around certain columns usually causes a progressive failure of the structure. The important sanction takes part in the TBC-500-2000 [6] and the other national design codes.

After the tower crane overturned, the important damage had been occurred on the $5^{\text {th }}$ floor side column and the different points of the same floor flat (Fig. 11-14). The effected side column had designed as rectangular shape as $300 / 1000$ $\mathrm{mm}$ according to the TBC-500-2000 and TEC-2007 [7] rules. The longitudinal reinforcement is $20 \$ 20$. The longitudinal reinforcement bars ratio is about 0.02 . The lateral ties are spaced $100 \mathrm{~mm}$ in the confinement zone and $150 \mathrm{~mm}$ in the middle zone.

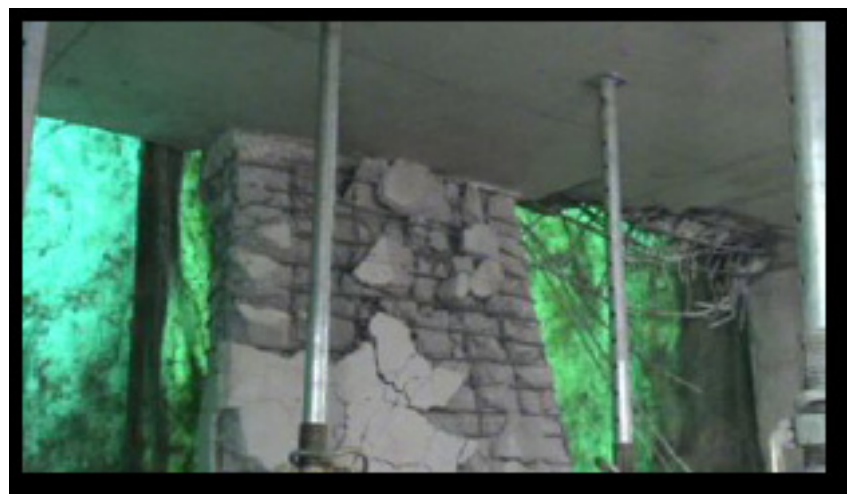

Fig. (13). The damaged slab and column.

It is easily seen that, the upper floor column has critical effect about punching failure when thinking only mentioned part of the reinforced concrete construction system. The punching strength of floor is given in equation 3;

$\mathrm{V}_{\mathrm{pr}}=\gamma \times \mathrm{f}_{\mathrm{ctd}} \times \mathrm{u}_{\mathrm{p}} \times \mathrm{d}$ 


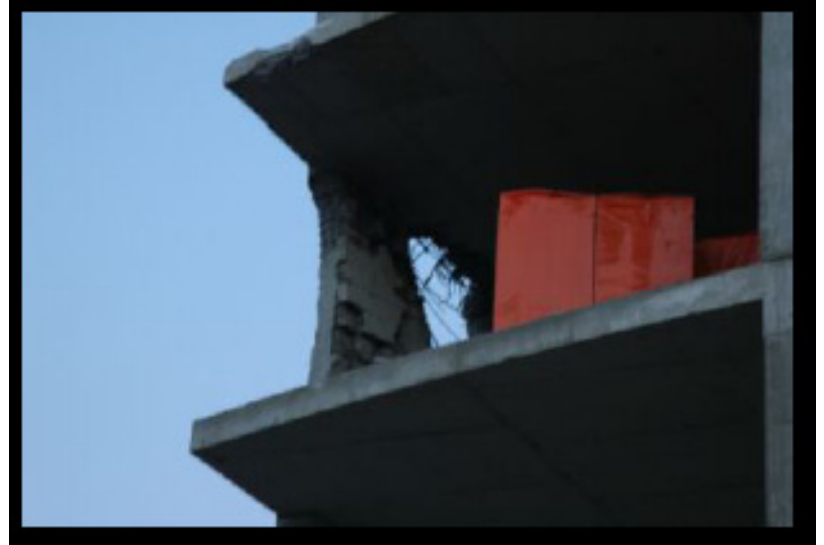

Fig. (14). $5^{\text {th }}$ floor corner column.

The shear around the column is increased when a moment has to be carried to or from to column. For columns subject to moments in addition to axial loads, the moment has to be transferred to the slab [8]. $\gamma$ is a coefficient that depends on the moment transfer. In the cases where the moment on the column is negligible, $\gamma$ can be taken as $1.0 \mathrm{ac}-$ cording to the TBC-500-2000. Design codes in general specify the critical perimeter at a distance $d / 2$ from the face of the critical column as called loaded area. In this example critical perimeter can be calculated as (Eq. 4).

$u_{p}=\left(30+\frac{d}{2}\right) \times 2+(100+d)$

$u_{p}=\left(30+\frac{24}{2}\right) \times 2+(100+24)=208 \mathrm{~cm}$

$\mathrm{V}_{\mathrm{pr}}=1.0 \times \frac{19}{1.5} \times 208 \times 24=63252 \mathrm{~kg}$

Design requirements for punching shear will be satisfied when the equation 6 is bigger than 1.0 .

$\frac{\mathrm{V}_{\mathrm{pr}}}{\mathrm{V}_{\mathrm{pd}}}>1.0$

In this equation, $\mathrm{V}_{\mathrm{pd}}$ is the punching shear and can be calculated as equation 5 ,

$\mathrm{V}_{\mathrm{pd}}=\mathrm{N}_{2}-\mathrm{N}_{1}-\mathrm{F}_{\mathrm{a}}$

$\left(\mathrm{N}_{2}-\mathrm{N}_{1}\right)$ is design shear, $\mathrm{F}_{\mathrm{a}}$ is the portion of the load remains within the critical section. The punching shear is calculated as $23400 \mathrm{~kg}$ according to the SAP2000 [9].

$$
\frac{23400}{63252}=0,369<1.0
$$

In this approach, although there was no dangerous situation in this section, right after the event took place, temporary supports were placed adjacent to the heavily damaged column and the column was suspended with the steel bars in the first stage. After that, the primary strengthened was performed and the causes of damage determined by examining the entire building. The suspended column was bonded by steel profiles. At the column-slap connection region the new steel member which can transfer the all shear force was placed. The shear member consists of two fabricated U 180 profiles and in order to increase shear capacity of the member 4 steel plates were added into profiles inner faces. In Fig. (15) and (16), the detail of this member is given.

After the strengthened stage of the column, all cracked and dissipated concrete was removed.

With the damage of the column, this region of the structural system has become as a console (Fig. 16). This situation would have caused the important deflection to increase in the slap system if the important precautions were not taken.

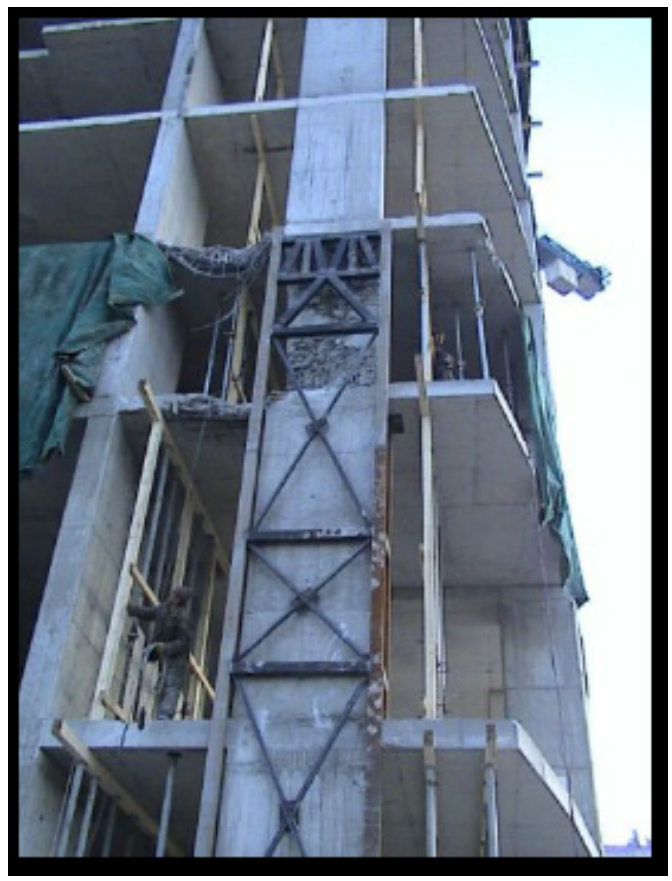

Fig. (15a). The column suspended with the steel bars.

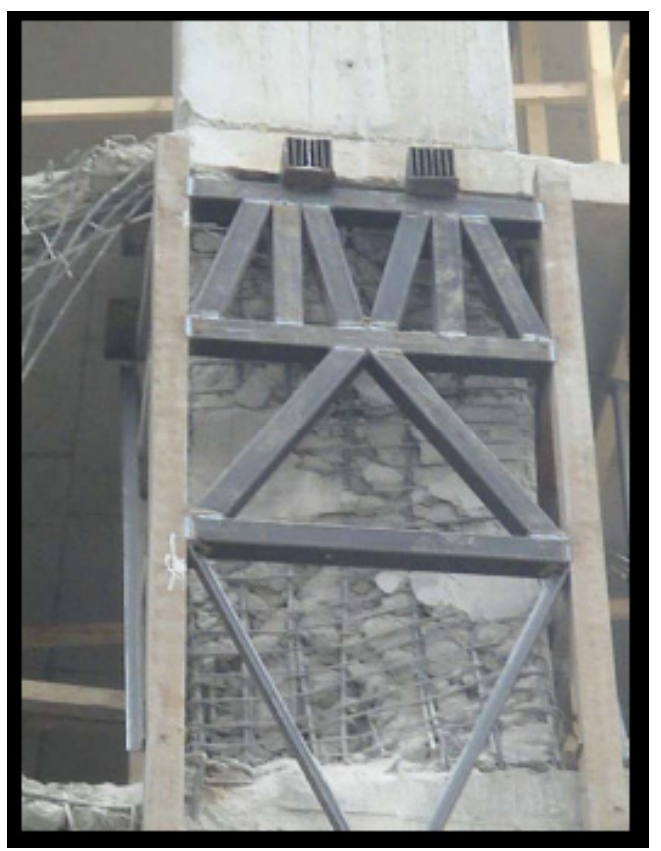

Fig. (15b). The column suspended with the steel bars. 


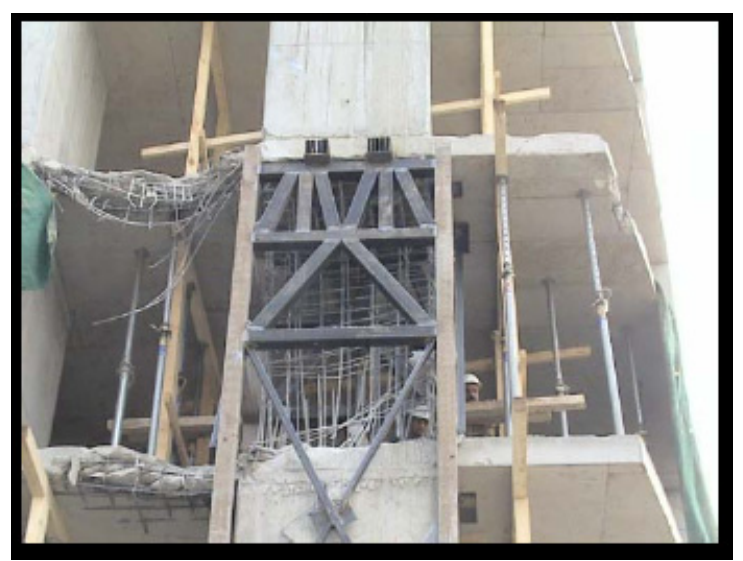

Fig. (15c). The column suspended with the steel bars.

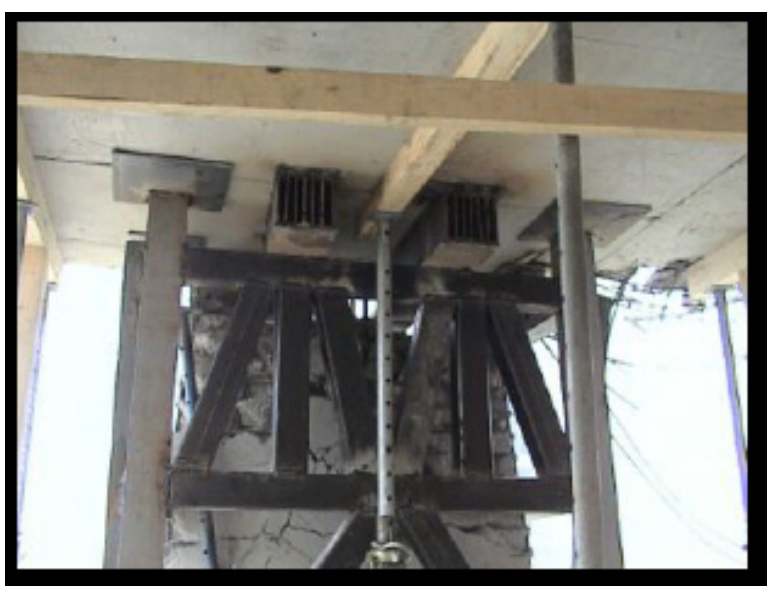

Fig. (16). Detail of the shear member.

The bended longitudinal steel bars with buckling were fixed in the column (Fig. 17).

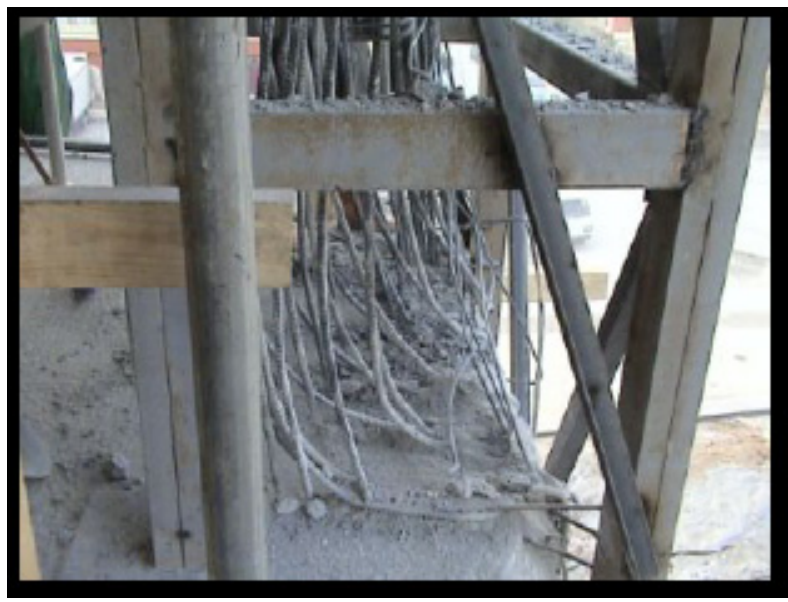

Fig. (17). The bottom of the column.

The flat slab thickness is $26 \mathrm{~cm}$ and after the tower crane crashing, three regional holes opened. These damages could not affect the rigid diagram behavior of the slab as seen in Fig. (18).
In the TEC-2007, conditions related to irregularities are defined. According to TEC-2007 rules, if any floor has the following defects,

- The case where the total area of the openings including those of stairs and elevator shafts exceeds $1 / 3$ of the gross floor area,

- The cases where local floor openings make it difficult the safe transfer of seismic loads to vertical structural elements,

- The cases of abrupt reductions in the in-plane stiffness and strength of floors,

TEC-2007 says that there will be floor discontinuities as called A2 in the buildings and it shall be verified by calculation in the first and second seismic zones that the floor systems are capable of safe transfer of seismic loads between vertical structural elements.

The building located in Konya city which is in the inactive seismic region $\left(4^{\text {th }}\right.$ degree) and the total areas opening with the accident is lower than $1 / 3$ of the gross floor area, there is no potential risk about transferring lateral (seismic) loads to the vertical structural elements.

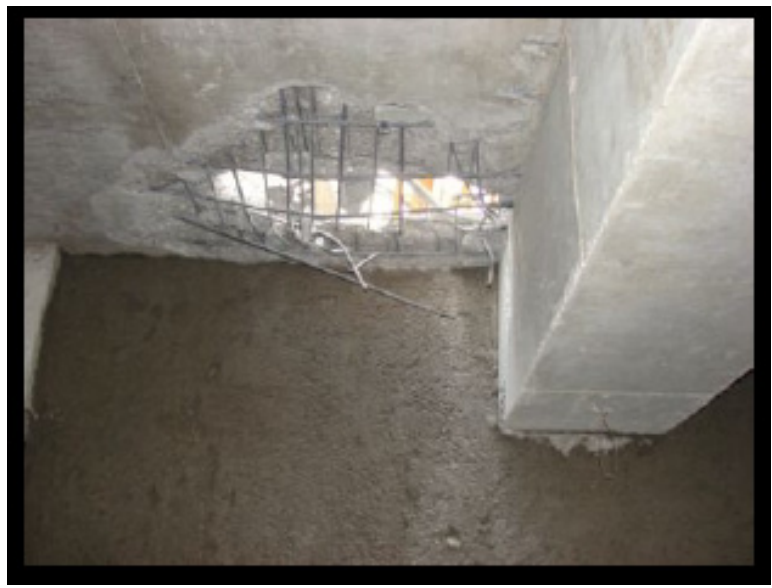

Fig. (18a). Failures and holes on the slab.

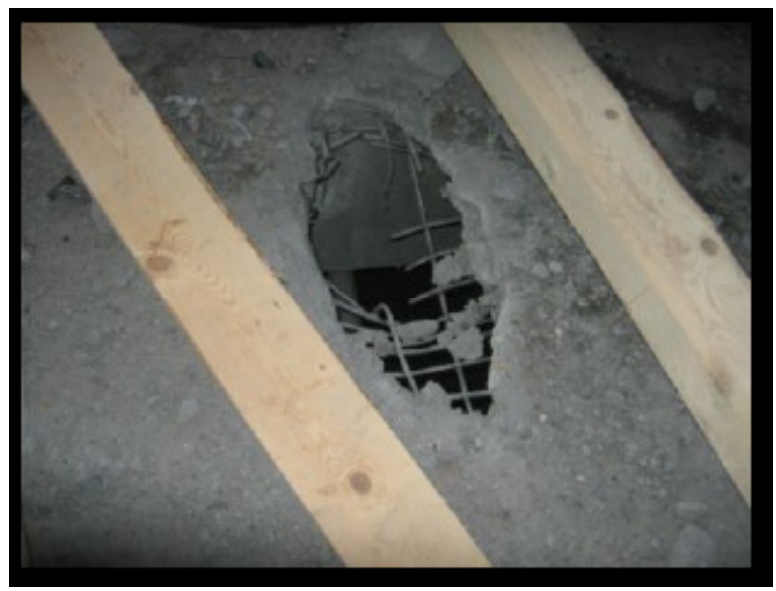

Fig. (18b). Failures and holes on the slab. 


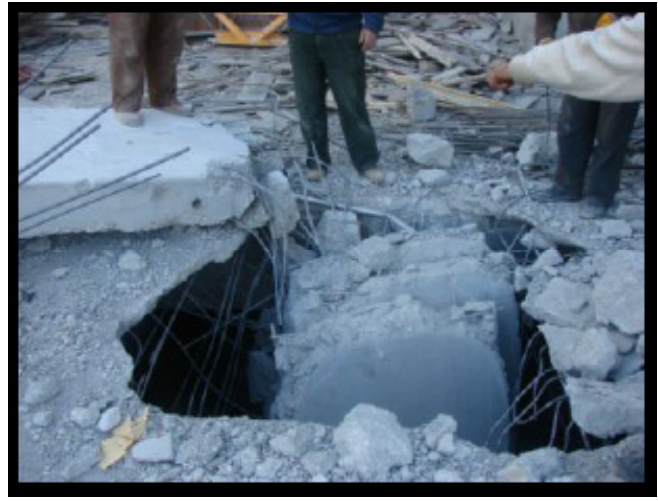

Fig. (18c). Failures and holes on the slab.

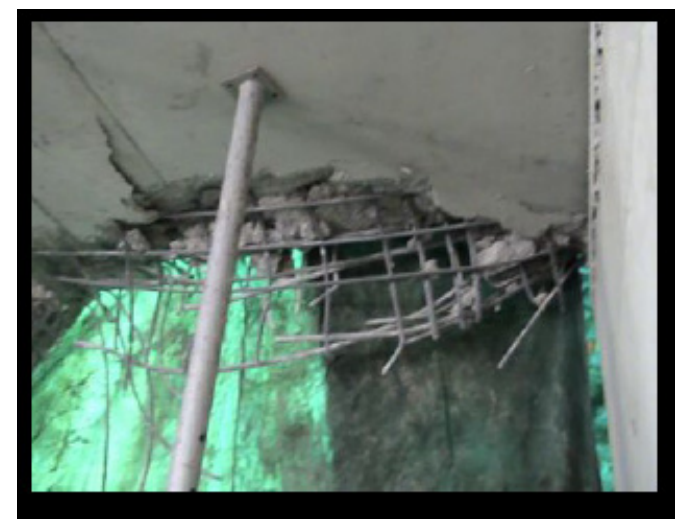

Fig. (18d). Failures and holes on the slab.

The roof and parapet system of the bakery belonging to Selcuklu Municipality located at the back facade of the building was mostly effected building. Since the members were prefabricated, they were easily changed after the accident. Fortunately, there was no occurring explosion in the LPG tank of the bakery as seen in Fig. (19).

\section{RESULTS AND DISCUSSION}

In this study, the accident occurred in Turkey in 2006 with the overturning of a tower crane in a construction site and the damage occurred on the nearby buildings due to this accident were taken into consideration. The accident has been analyzed and the main reasons of this failure have determined as;

- Not having a regular platform on which the crane foundation was settled during the assembly of the crane.

- Not using anchorage members fixed the crane footings.

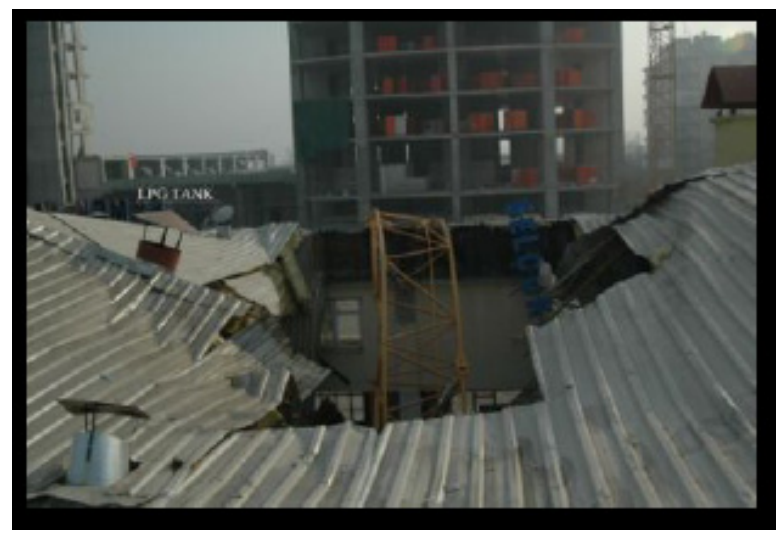

Fig. (19). The roof and parapet system of the bakery.

- Not using the connection member between the crane and building.

- The extreme load at the end of the crane arm.

After the tower crane overturned, the important damage had been occurred on the $5^{\text {th }}$ floor side column, the different points of the same floor flat and also the roof and parapet system of the adjacent bakery. According to the calculation using related codes the structural system members as column and slab damages have not been important stage. Although there was no dangerous situation in this section, right after the event took place, temporary and permanent precautions were taken.

\section{ACKNOWLEDGEMENTS}

The authors acknowledge support provided by S.Bekdik and S.Eser.

\section{REFERENCES}

[1] Liebherr, The Crane Systems, Handbook. [Online] Available;www.liebherr.com [Accessed Aug. 15, 2007].

[2] TS-ISO 8566-3, Cranes-Cabins, Ankara, TSE Press, 1998

[3] TS-ISO 4306-3, Cranes-Controls-Layout and characteristicsPart3: Tower cranes, Ankara, TSE Press, 1997.

[4] http://www.okyanus-tr.com/?sec=502 [Accessed Aug. 29, 2007].

[5] S. Bekdik, "The expert report of the crane accident", Konya,Turkey. March 25, 2006.

[6] TBC-500-2000, Turkish Building Code, Ankara, TSE Press,2000.

[7] TEC-2007, Turkish Earthquake Code for Buildings in Hazardous Areas, Ankara, pressed by Ministry of Public Worksand Settlement, 2007.

[8] U. Ersoy, Reinforced Concrete, Ankara, Evrim Press, 1997.

[9] E.I. Wilson and A. Habibullah, SAP2000 v9 and NonlinearVersion7.2, Integrated Software for Structural Analysis and Design, Computers and Engineering Press, Berkeley,1999.

CArslan and Kaltakci.; Licensee Bentham Open.

This is an open access article licensed under the terms of the Creative Commons Attribution Non-Commercial License (http://creativecommons.org/licenses/by-nc/3.0/) which permits unrestricted, non-commercial use, distribution and reproduction in any medium, provided the work is properly cited. 